\title{
ADAM10 wt Allele
}

National Cancer Institute

\section{Source}

National Cancer Institute. ADAM10 wt Allele. NCI Thesaurus. Code C91859.

Human ADAM10 wild-type allele is located in the vicinity of $15 q 22$ and is approximately $155 \mathrm{~kb}$ in length. This allele, which encodes disinteg rin and metalloproteinase domaincontaining protein 10 , is involved in the modulation of plasma membrane protein shedding. 